\title{
Biallelic Mutation
}

National Cancer Institute

\section{Source}

National Cancer Institute. Biallelic Mutation. NCI Thesaurus. Code C129829.

A mutation that occurs on both alleles of a single gene. 